\title{
Jerzy Kiełbik
}

\section{ADMINISTRATION OF THE WARMIA REGION IN THE LIGHT OF ITS DOMESTIC LAWS}

\author{
Słowa kluczowe: $\quad$ ustawy krajowe, życie codzienne, Warmia, historia prawa \\ Schlüsselwörter: $\quad$ Landesordnungen, Alltag, Ermland, Geschichte des Rechts \\ Keywords: $\quad$ domestic law, daily life, Warmia, history of law
}

During the First Polish Republic (I Rzeczpospolita), Warmia was a small state under the secular leadership of the clergy: the Bishop and the cathedral chapter. This is important inasmuch as the Bishop simultaneously exercised the religious leadership over the region and, in terms of the canon law, was the head of the chapter. However, in secular, administrative or judicial matters, the aforementioned corporation and the Bishop had no influence on the activities of one another. Analysing the issue, Alojzy Szorc ${ }^{1}$ concludes that due to the continuity of the chapter's operation and its provisional management in periods when the bishop's seat was vacant, the position of the Bishop as the secular leader was slightly weaker. Nevertheless, this administrative division did not affect the necessity for regular cooperation of both sides, at least for practical reasons. Another kind of cooperation, but of a completely different nature and extent, occurred also with the neighbouring Duchy of Prussia 2 .

The territory of Warmia, surrounded by the state of Prussia, resembled a trapezoid extending from the Vistula Lagoon towards the south-east, covering an area of $4249 \mathrm{~km}^{2}$. The borders of Warmia were partially based on hydrographic elements: the western border ran along the Pasłęka river, while the south-east border extended along the ridgeline between Pasłęka and Łyna on the one side and the tributaries of the Narew river on the other ${ }^{3}$. From the point of view of secular ad-

${ }^{1}$ A. Szorc, Dominium warmińskie 1243-1772. Przywilej i prawo chetmińskie na tle ustroju Warmii, Olsztyn 1990, p. 45.

${ }^{2}$ J. Kiełbik, Wspótpraca ponad granica. Kontakty Warmii i Prus Książęcych w XVI wieku, Komunikaty Mazursko-Warmińskie (KMW), 2006, no. 2, pp. 219-223.

${ }^{3}$ S. Zajchowska, Geografia, in: Warmia i Mazury, ed. by S. Zajchowska and M. Kiełczewska-Zaleska, vol. II, Poznań 1953, p. 8; A. Poschmann, Die Siedlungen in den Kreisen Braunsberg und Heilsberg, Braunsberg 1910, pp. 3-13; G. Labuda, Środowisko geograficzne, in: Historia Pomorza, vol. I from year 1466, ed. by G. Labuda, Poznań 1969, pp. 15-27. 
ministration, Warmia was divided into ten districts (komornictwa). Their names derived from their cities and administrative centres. Three districts were subject to the cathedral chapter: the Frombork, Melzak and Olsztyn districts ${ }^{4}$, while the other seven: Braniewo, Orneta, Dobre Miasto, Lidzbark, Jeziorany, Reszel and Wartemborg districts were managed by the Bishop 5 . The districts were headed by burgraves, who had broad judicial and administrative powers. Additionally, the rulers had other officers to assist them. Among other things, the Bishop appointed a vogt (wójt) to help him defend his territory, and a treasurer to manage his property. This was in contrast to the chapter, which used to elect an administrator from among its members (its most well-known administrator was Nicholas Copernicus). The position of the chapter vogt, however, despite having been initially granted with powers similar to his bishopric counterpart, eventually lost its military character. The division of church structures to archpresbyterates functioned independently of the above-mentioned system and did not overlap with it in any extent ${ }^{6}$.

In the then Poland, Warmia was a unique ereation. It was ruled by the clergy, while the nobles, dominant throughout the Polish Republic, played a minor role in the region. Moreover, the properties assigned to peasant or knight land holdings, regardless of whose hands they were in, sometimes made the members of these privileged groups perform the duties normally belonging to someone of lower status ${ }^{7}$. Additionally, it was absolutely unprecedented in the whole Republic that the nobility should have no right of appeal to the king against the decisions of the Warmia courts 8 . Apart from the nobility, there were also townspeople, village heads (sołtysi) and free men (wolni) who played important roles in the region, participating in government through the Warmia assembly (sejmik). This was another unique feature that distinguished Warmia from other regions of Poland.

The Warmia society was dominated by priests, who were not so much landlords as territorial rulers. In addition, they combined secular and ecclesiastical authority which made their power extend farther than in the case of lay overlords. Authority in one area was often used in another, and the consequences were far-reaching. The best example of this is a document from 1570 issued by Bishop Marcin Kromer, the so-called Kirchgangsedict. It edict imposed on all believers,

${ }^{4}$ Melzak, a city in northern Warmia - nowadays Pieniężno.

${ }^{5}$ T. Borawska, Tiedemann Giese (1480-1550) w życiu wewnętrznym Warmii i Prus Królewskich, Olsztyn 1984, p. 55; Wartenbork, a city in southern Warmia, nowadays Barczewo.

${ }^{6}$ A. Olczyk, Sieć parafialna biskupstwa warmińskiego do roku 1525, Lublin 1961, p. 21.

${ }^{7}$ There was such an incident that happened to the widow of Andrzej Pilchowicz, brother of Warmia suffragan Wojciech, in 1664; see: S. Achremczyk, Szlachta na Warmii XVI-XVIII wieku, in: Szlachta i ziemiaństwo na Pomorzu w dobie nowożytnej XVI-XX wieku (Przemiany struktur wewnętrznych), ed. by J. Dygdała, Toruń 1993, p. 64.

${ }^{8}$ A. Szorc, op. cit., p. 370 and n. 
especially parents, children aged 10 and up and domestic servants, the duty of participation in the Sunday and holiday masses under the threat of sanctions (including administrative ones) ${ }^{9}$. As can be seen, the rights normally belonging to landlords were used in this case to exact the fulfilment of believers' duties.

In the work, 'Polska, czyli o położeniu ludności, obyczajach, urzędach i sprawach publicznych Królestwa Polskiego, written in the 16th century, the already mentioned Bishop Marcin Cromer wrote: The Warmia Bishopric does not belong to any voivodeship: it has specially demarcated clear boundaries delimiting one continuous area, resembling that of a duchy, with castles and cities in it. And it was divided so as to grant power over two parts to the Bishop, and to the college, that is, the chapter, over the third. In their territories, the Bishop and the chapter have power over the nobles and control over courts which are free and independent of the jurisdiction of any royal officials ${ }^{10}$. It should be noted here that, in fact, Warmia consisted of two separate entities: the dominion, which until 1525 formed third part of the diocese, and where the Bishop's and the chapter's secular and religious power coincided, and the diocese proper ${ }^{11}$. After the secularisation of the Teutonic Order, the dissimilarity between the territories of these two organisms persisted, despite a significant reduction in the area of the other entity. An example of this was Elblag, which was subject only to the church jurisdiction of the Warmia bishops.

The process of formation and development of the Warmia government system was strenuous and lengthy. In order to understand its nature, it is necessary to focus our attention to a somewhat forgotten fact. The fluidity and elasticity of the medieval legal norms and their wide interpretation by the modern researchers is perfectly seen in case of Warmia ${ }^{12}$.

Warmia was established on the territories inhabited by Prussian tribes which for centuries constituted a huge temptation and a direction of expansion. This desire was aggravated by the fact that the Christian doctrine allowed to treat them as nobody's land, 'res nullius' ${ }^{\prime 3}$. It is no wonder, therefore, that the Polish state tried to expand its territory at its expense. Missions and crusades were undertaken, yet they did not bring the desired effects; to the contrary, the weakness of Poland resulting from its division to smaller states in the period of feudal fragmentation (rozbicie dzielnicowe) rendered the expansion plans unfeasible. The Prussians

\footnotetext{
${ }^{9}$ W. Nowak, Geneza agendy biskupa Marcina Kromera, in: Agendy i rytuały Diecezji Warminsskiej (1574-1939), ed. by W. Nowak, Olsztyn 1999, p. 19.

${ }^{10}$ M. Kromer, Polska czyli o położeniu ludności, obyczajach, urzędach i sprawach publicznych Królestwa Polskiego księgi dwie, Olsztyn 1977, p. 175.

${ }^{11}$ On the geography of Warmia, see: A. Szorc, Dzieje Warmii 1454-1660. Stan badań i postulaty badawcze, Olsztyn 1999, pp. 11-18.

${ }^{12}$ D. Bogdan, Sejmik warmiński w XVI i pierwszej połowie XVII wieku, Olsztyn 1994, p. 13.

${ }_{13}$ J. Sikorski, Monarchia polska i Warmia u schyłku XV wieku. Zagadnienie prawno-ustrojowe i polityczne, Olsztyn 1978, p. 16.
} 
themselves were not peaceful neighbours either. They attacked the border areas, looting and burning Christian settlements in Masovia and Ruthenia. In order to stop the penetration of the country and to ensure the conquest and christianisation of Prussia, Konrad Mazowiecki brought the Teutonic Order to Poland and established it in the Chelmno Land. The Order, however, did not intend to convert the Prussians, yet it constituted a force able to seize the territory and prepare grounds for the missionaries ${ }^{14}$.

There was also something also else the Order did. By receiving papal and imperial privileges, it managed to organise its own state in the occupied territories ${ }^{15}$. The conquered land was split between the Church and the Order in the proportions 1:2, based on the bull of 29 July 1243 . At the same time, by establishing four dioceses: the Chełm, Pomesania, Warmia and Sambia diocese, the church structure was formed. The 'Noverit universitas vestra', written by William of Modena, a papal legate, determined the state's borders ${ }^{16}$ (the borders of the dominion were eventually established in 1375 and were preserved until 1772) ${ }^{17}$. The document reserved the legal equality of the Bishop and the Order which, being both in possession of the land with 'all its incomes' and 'any jurisdiction and law', were to be directly subject to Rome ${ }^{18}$. As the idea of the Warmia diocese was yet to emerge, the area was still called the third diocese. The term 'Warmia' does not appear in the document establishing the diocese. The first time the diocese was named in this way was in the Bishop Anselm's nomination of 6 October1250 issued in Lyon ${ }^{19}$. The newly appointed Bishop began his ruling by organising and colonising his dominion, which resulted in establishing the cathedral chapter of Braniewo in 1260. After its foundation, Warmia once again was divided. Bishop Anselm granted its third part to the chapter, considering it an equal partner ${ }^{20}$.

Braniewo, the first capital, did not keep its status for long, as already during the 1260 Prussian uprising the city was destroyed, and the original wooden St. Andrew's Cathedral was burned. Anselm's successor, Henryk Fleming, moved the chapter in 1278 to Frombork, due to its greater defensive potential. In years 13291388, a new gothic cathedral was built there. The bishops themselves did not reside together with the chapter. They first chose Braniewo as their seat, then moved to Orneta and settled finally in Lidzbark Warmiński ${ }^{21}$.

\footnotetext{
${ }^{14}$ A. Szorc, Dzieje Diecezji Warmińskiej, Olsztyn 1991, p. 16.

${ }^{15}$ On the establishment and functioning of the Teutonic state; see: M. Biskup, G. Labuda, Dzieje Zakonu Krzyżackiego w Prusach. Gospodarka - Społeczeństwo - Państwo - Ideologia, Gdańsk 1988.

${ }^{16}$ A. Kopiczko, Ustrój i organizacja diecezji warmińskiej w latach 1525-1772, Olsztyn 1993, p. 12.

${ }^{17}$ A. Szorc, Dominium warmińskie, p. 25.

${ }^{18}$ D. Bogdan, op. cit., p. 14.

${ }^{19}$ A. Szorc, op. cit., p. 23.

${ }^{20}$ Ibidem, pp. 14-15.

${ }^{21}$ J. Obłąk, Historia Diecezji Warmińskiej, Olsztyn 1959, p. 20.
} 
At this point, one should take a closer look at the legal and systemic position of the bishopric in the Teutonic state. Was it a sovereign body or did it exist in a form of dependence? According to Bogusław Leśnodorski, since the division in 1243 Warmia did not possess sufficient legal grounds or actual capabilities to be completely independent and unrestricted in its sovereignty ${ }^{22}$. The Order was entrusted with the conquest of Prussia and the defence of the whole country - including the properties of the bishops; this fact alone helped it to take the initiative and leadership in 'domestic affairs' ${ }^{23}$. Because of this, the Order claimed the right of staffing the posts of vogts, which it readily did within the Bishop's domain, a fact that never took place in the part managed by the chapter.

Danuta Bogdan, summing up her views on the role of the Warmia region in the Teutonic state, stated that: ,the first Warmia diocese was, from its very beginning, a crucial part of the Teutonic state. Nevertheless, it managed to establish a significantly autonomous legal and economic administrative unit within its bounds. The Order's supremacy over it stemmed mainly from the nature of the function the Teutonic knights were entrusted with, namely, the defence of the territory and the preservation of the state's unity. 2. Despite the fact that the knights dominated the other Prussian bishoprics, Warmia remained independent by maintaining the ssecular' character of the chapter and its election by the bishops who were not members of the Order ${ }^{24}$.

Another important issue to strongly influence the specific character of Warmia was its incorporation to the Polish Crown, or, rather, the nature and content of the legal acts on the basis of which it was done. The topic of the military struggle between the Teutonic Order and Poland is a thoroughly explored subject and does not need a detailed reminder. Similarly to Royal Prussia, Warmia became part of Poland as a result of the Thirteen Years, War. It was, however, a complex process that consisted of a number of legal acts. First, Warmia was included in the incorporation act of 1454 issued by Casimir IV Jagiellon. The king's delegation included the representatives of the cathedral chapter, canons Jan Plastwich and Herman von Birken and the mayor of Braniewo, Jan Calais; however, these people can hardly be considered the official delegation of Warmia, particularly insomuch as there is no Bishop's representative among them ${ }^{25}$. What is even more interesting is the fact that the Bishop, Francis Kuhschmalz, sided with the Teutonic knights. As a result, he had to seek refuge, first in Malbork, and then in Wrocław, where he died in 1457 . His successor, Paul Legendorf, initially pursued a neutral policy to-

\footnotetext{
${ }^{22}$ B. Leśnodorski, Dominium warmińskie (1243-1569), Poznań 1949, p. 12

${ }^{23}$ J. Sikorski, op. cit., pp. 24-25.

${ }^{24}$ D. Bogdan, op. cit., pp. 26-27.

${ }^{25}$ Ibidem, p. 21.
} 
wards the two conflicting forces. He regained castles and towns from the Poles and from the Order alike. However, the success of the former group encouraged him to change his attitude and to seek contact with the Prussian states. On 16 March 1464, the so-called perpetual peace agreement was signed in Elblagg between the Bishop and Warmia chapter on the one hand, and the king and the states of Prussia on the other. The treaty involved, among other things, the following statement: 'the king promised to keep all the privileges, freedoms, rights, jurisdiction and customs which the Warmia Lord Elect has long enjoyed together with his Church, chapter and citizens, and to support and defend all of the mentioned privileges ${ }^{26}$. This was later confirmed by Casimir Jagiellon in a document issued in Nowe Miasto Korczyn on 5 May $1465^{27}$.

These two acts are complemented by the third one. In accordance with the provisions of the Second Peace of Thorn of 1466, Warmia was incorporated into Poland together with the whole territory of Royal Prussia. Leśnodorski argues that the dominion gained at least one thing during this turbulent period: 'the confirmation, already in the incorporation act, of the Prussian rights and privileges, and therefore, also of the particular interests of Warmia, as well as the provision of new rights and a solemn assurance of the royal protection in a separate act of $1464^{228}$. Analysing the situation of Warmia in Poland, it is possible to point out some key points in its history: a) the Bishop assumed the position of senator of the Crown and Prussia, which matched the dignity of his office. Since the times of Bishop Lukas Watzenrode, the position of senator was combined with being the head of the Prussian generalship; b) the population of Warmia was directly subordinated to the king; c) in Warmia's attitude towards Royal Prussia, there is an absence of legal rules separating the dominion from the Prussian province which was arranged and governed by norms deriving from the incorporation privilege and the peace treaty with the $\operatorname{Order}^{29}$. An attempt to explain the mutual relations of these two political and legal states was undertaken by Karol Górski. He noted that Royal Prussia was a 'complex country' with Warmia forming its part as 'a small state'30.

The Polish kings treated the privileges that they granted inclusively. Their aim was to integrate the newly acquired territories to the rest of Poland, yet some privileges stood in the way of this. The kings not only did not intend to observe the right of the 'indygenat' (the grant of nobility to foreign nobles) of the candidates for the Bishop's throne (the province's rights in this matter were not overtly violated, but rather gradually departed from), but they wanted to have full con-

\footnotetext{
${ }^{26}$ A. Kopiczko, op. cit., p. 34.

${ }^{27}$ D. Bogdan, op. cit., p. 22.

${ }^{28}$ B. Leśnodorski, op. cit., p. 31.

${ }^{29}$ Ibidem, p. 51.

${ }^{30}$ K. Górski, Problematyka dziejowa Warmii, KMW 1977, no. 2, pp. 173-174.
} 
trol of who will occupy it. Against this background, a war broke out between the Bishop Tungen, elected by the chapter, and Casimir Jagiellon (War of the Priests of 1478-1479). Eventually, a settlement was reached on 15 July 1479 which stipulated that the chapter was to elect the candidate who was ,to the king's liking. This by no means ended the dispute, as already the choice of the next Bishop spurred another disagreement. The chapter pretended it did not understand the term ,to the king's liking' as meaning, indicated by the king'. A conflict broke out between the newly elected Bishop Lukas Watzenrode and Casimir Jagiellon. Eventually the issue was resolved by a new agreement concluded on 7 December 1512, and ratified by the chapter on 26 December of the same year. This, as well as subsequent practice, strengthened the role of the monarch in the election of bishops. Formally, the chapter chose from among four candidates designated by the king, but in fact the only one counting was the first candidate.

Still, Warmia never merged completely either with Royal Prussia or even with the Republic of Poland. It cherished a far-reaching independence and autonomy, with its rulers successfully fighting to keep their privileges. A good example that demonstrates his is the fact that the subjects of the Bishop and the chapter had the right of appeal to the royal court, which reflected the attempts of the region's unification. Throughout the 16 th and 17 th century, the right was seldom employed, only to be ultimately cancelled in $1655^{31}$. The bishops themselves, despite being imposed by the king and often coming from other parts of the Republic, were limited as nowhere else in Poland by means the so-called articuli iurati (artykuły zaprzysiężone $)^{32}$. The articles obliged the bishops, among other things, to respect the rights and sovereignty of Warmia.

This autonomy was further strengthened by the ,Observationes communes', which was a general set of rules established on the basis of wilkierze (systems of administrative laws), ad hoc decisions of the assemblies and long-established custom. It concerned a variety of areas, ranging from the methods of sealing documents by the Bishop and the chapter, to the serfdom redemption ${ }^{33}$.

The last attempt to interfere with the rights and freedoms of the dominion in the Poland before the partitions occurred during the Stanisław Poniatowski's Convocation sejm. The sejm decided that the chapter should send delegates to the Crown Tribunal and that its members were to be exclusively from the nobility. Eventually, after a determined resistance on the part of canons and the support of the Bishop Adam Stanisław Grabowski, these adverse demands were withdrawn ${ }^{34}$.

\footnotetext{
${ }^{31}$ D. Bogdan, op. cit., p. 24.

${ }^{32}$ A. Szorc, Dzieje Warmii, p. 75.

${ }^{33}$ Idem, Dominium warmińskie, pp. 111-112.

${ }^{34}$ Idem, Zagrożenie Warmii przez Prusy (1722-1772), KMW 1972, no. 4, p. 531.
} 
An important element contributing to the legal specificity of Warmia were its internal laws. Kromer defined them in the following way: ,the subjects of the Bishop and the Warmia chapter are governed by the same national laws as the other inhabitants of Prussia, but they also have their own laws which they call Landsordnung, that is, country ordinance ${ }^{35}$. Such country ordinances, existing also in Prussia (but not in Poland), resembled wilkierze ${ }^{36}$, which were defined by Zygmunt Gloger as 'the arrangements of the common people accepted by the authorities $^{37}$ and formed an extension of and a complement to the Chełmno Law ${ }^{38}$. Apart from the national wilkierze we are interested in, there were also urban, rural and craftsmen's wilkierze which concerned similar topics but were of a lesser impact. They were all written in German, and the two preserved copies that are exception to the rule (one written in Polish, the other in Latin) are only translations ${ }^{39}$. National laws, despite their lofty name, mostly contained specific rules relating to daily life, for example, on servants, work discipline, trade, markets and fairs, the cultivation of land, etc. It is worth emphasizing that particular stress was placed on the correspondence of the provisions concerning the servants and craftsmen with the norms in force throughout Prussia, as there was a real threat of mass servant migration and an economic downturn in case they remained dissimilar ${ }^{40}$.

Wilkierze demonstrated manifestations of two different wills: the will of the society and of the authorities. The society's will was manifested in the fact that changes to laws were introduced, as a rule, following the requests and suggestions of the subjects ${ }^{41}$.

In the period 1243-1772 in Warmia, the following domestic ordinances were published:

1) Bishop Franciszek Kuhschmalz's of 1427. (it tackled the native element, trying to subjugate it, and contained provisions about servants, trade and crafts, limitations in lavishness of weddings and christening parties);

2) Bishop Lukas Watzenrode's of 1505. (contained provisions concerning: weights and measures, craftsmen and servants, trade, assemblies, propination, equipment of persons liable for military service, discipline);

3) Bishop Maurycy Ferber's of 1526. (the most complete to date and later, up to 1766, of all published. It contained provisions relating to: the Catholic religion, deputies, councillors, guildhouse masters, church holidays, tithes, wills,

${ }^{35}$ M. Kromer, op. cit., pp. 175-176.

${ }^{36}$ A. Szorc, Wilkierze warmińskie, Studia Warmińskie, 1984, vol. XXI, p. 5.

${ }^{37}$ Encyklopedia staropolska ilustrowana, ed. By Z. Gloger, vol. 4, Warszawa 1958, p. 437.

${ }^{38}$ A. Szorc, Wilkierze warmińskie, p. 5; this article describes all types of wilkierze: urban, rural and craftsmen's wilkierze.

${ }^{39}$ Ibidem, p 8.

${ }^{40}$ Ibidem, p. 9.

${ }^{41}$ Ibidem. 
maintenance of church buildings, responsibilities of church administrators, capital contributions, capital investments, limitations to weddings and christening parties, division of estate, trade, weights and measures, sowing and storage of linseed, brewing, restrictions for peasants, poaching bans);

4) Bishop Mikołaj Szyszkowski's of 1636-1637 (contained the following provisions: on desertion and extradition of peasants between Prussia and Warmia, renting and remuneration of servants and day labourers, merchants, brewers, price lists for goods and services, clothes);

5) Bishop Krzysztof Szembek's of 1730. (entirely related to servants and day labourers $)^{42}$.

Of all the Warmian laws, two were crucial. The first was the 1526 bill issued by Bishop Maurycy Ferber. It focuses primarily on religious questions, since, one has to remember, it was passed a year after the secularisation of the Royal Prussia. In addition, it encompasses all aspects of the socio-economic life in Warmia. It also regulates issues relating to agriculture, flax cultivation in particular, and introduces enforcement regulations. A thorough discussion of the document is presented by Alojzy Szorc ${ }^{43}$ and Thomas Berg ${ }^{44}$, and, in the context of Nicolaus Copernicuss participation in its creation, by Danuta Bogdan ${ }^{45}$. Therefore, it only seems necessary to remind that the document consists of 37 articles, and, as usually in case of such legal acts, it bears the burden of its times: the recent Polish-Teutonic war and the reformation. It is the latter that led to the fact that the act regulates issues related to religion in the first place. In view of the changes in Prussia associated with its secularisation, it became crucial for the clergy and diocese officials, having lost about $2 / 3$ of the diocese area in favour of the Protestant Church, to slow down the reformation processes. It is therefore not surprising that these provisions were placed at the very beginning of the document, even preceding the issues related to taxes. The act prohibited religious disputes, distribution of heretic texts, and even obliged the master craftsmen to control if their apprentices fulfilled their religious duties. It is only in the second place that the law discusses the issues of oaths of loyalty to lord superior, celebration of Church holidays and craft guild anniversaries, and tithing. Tithes had to be paid from St. Martin's Day (11 November) until Candlemas (2 February). In the remaining part, the laws laid down by Ferber addressed the problems of wills (introducing mandatory bequests for the Church), maintenance and construction of church buildings, and reports of church administrators. A significant part of the regulation dealt with the or-

\footnotetext{
${ }^{42}$ A. Szorc, Dominium warmińskie, pp. 108-109.

${ }^{43}$ A. Szorc, Wilkierze warmińskie, pp. 18-24.

${ }^{44}$ T. Berg, Landesordnungen in Preußen vom 16. bis zum 18. Jahrhundert, Lüneburg 1998.

${ }^{45}$ D. Bogdan, Warmińska ordynacja krajowa "Landesordung” z 1526 roku i kwestia udziału w jej redakcji Mikołaja Kopernika, KMW, 2013, no. 2, pp. 283-293.
} 
ganizational-economic questions: capital investments in real estate, restrictions in the lavishness of family celebrations, and bequests. The provisions were largely mixed up among themselves: organisational rules appeared next to bequests, etc. Furthermore, much space was devoted to cases related to trade. Regulations were introduced to market buying and selling, normalisation of weights and measures, as well as production of beer and its retail in taverns. Attempts were also made to restrict the reportedly excessive flax cultivation ${ }^{46}$.

Subsequent ordinances were rather selective in character, which has been already mentioned above. However, over time, changes in Royal Prussia as well as internal changes in Warmia caused by wars and destruction brought the necessity of reform. It was not until 1766 when the reform was carried out. Its enforcement was primarily thanks to the interaction of two persons: Bishop Adam Stanisław Grabowski, and his right hand, canon Tomasz Szczepański. It is also worth to highlight the procedure associated with the preparation of the act which shows a mutual cooperation in the country's management and Warmia people's engagement ${ }^{47}$.

First, an attempt was made to obtain the approval of the cathedral chapter. To this end, a letter was sent by the Bishop on 18 January 1766 via the general treasurer, canon Tomasz Szczepański ${ }^{48}$. Szczepański not only delivered the letter, but also explained to the chapter the necessity of reforming outdated regulations and asked the chapter to send delegates or commissioners to undertake this task ${ }^{49}$. The official reading of the letter and the communication of the chapter's stance took place at the general meeting on St. Agnes's Day (21 January) ${ }^{50}$. The response was sent on 23 January 1766. It stated that 'for the sake of efficient governance of the diocese, nothing is more desirable presently than the modification of old laws and the possible adoption of new regulations that match better with contemporary realities ${ }^{\prime 51}$. At the same time, it was proposed that a commission meeting should be held on 15 March in Orneta ${ }^{52}$.

The date was not observed. The amount of preparatory work made it necessary to postpone the meeting ${ }^{53}$, the more so as the preparations, as Anton Eich-

${ }^{46}$ A. Szorc, Wilkierze warmińskie, pp. 18-24.

${ }^{47}$ For an extensive commentary on the law and its legislation, see: Ustawa krajowa biskupa Adama Stanisława Grabowskiego z 4 lipca 1766 roku, Introduction by Jerzy Kiełbik, trans. Magdalena I. Sacha, Olsztyn 2010; J. Kiełbik, Ankieta dobromiejska, KMW, 2002, no. 4, pp. 527-533; J. Kiełbik, Komornictwa kapitulne wobec reformy społeczno-gospodarczej z 1766 roku, KMW, 2003, no. 2, pp. 221-235; J. Kiełbik, Ustawa krajowa Adama Stanisława Grabowskiego z 4 lipca 1766 roku, KMW, 2002, no. 2, pp. 213-240.

${ }^{48}$ A. Szorc, op. cit., p. 49.

${ }^{49}$ Archiwum Archidiecezji Warmińskiej w Olsztynie (AAWO) AK, Ab 38, p. 366.

50 A. Eichhorn, Geschichte der ermländischen Bischofswahlen, Zeitschrift für die Geschichte und Altertumskunde Ermlands, 1863, Bd. 2, p. 459.

${ }^{51}$ After A. Szorc, op. cit., p. 50.

${ }^{52}$ AAWO, AK, Ab 38, p. 367; A. Szorc, op. cit., p. 50.

${ }_{53}$ T. Berg, op. cit., p. 220. 
horn points out, were not particularly hasty ${ }^{54}$. A work so important and complex, as the new country law was, required understanding, expertise, and knowing the opinion of the subjects. In the Bishop's Curia on 28 February, an address to the public was prepared which, after its endorsement by the chapter, was published on $3 \mathrm{March}^{55}$. It stressed the necessity of passing a new law since the Bishop Ferber's ordinance was already outdated 'theils wegen ihres Alters, theils aber wegen Vernachlessigkeit ${ }^{56}$ (it is very significant that only the act of 1526 is mentioned; this clearly indicates that it was considered superior to all the subsequent regulations). The appeal also pointed to a number of violations which crept into the public life and the potential of new law to rectify this state of affairs so that all the social classes returned within the limits intended for them.

However, if this was supposed to work, the commission gathering to prepare the text of the act on April 141766 in Orneta needed to obtain some information about the most pressing issues of the Warmia inhabitants. For this purpose, after receiving the appeal, burgraves were to summon to their office the nobles, village heads, councillors and free men by means of circular letters and on a given day, but nolater than 8 days prior to the meeting of the commission itself. The gathered representatives were to answer 14 written questions and send their answers back to the commission. Such procedures were required from the authorities of cities and their inhabitants. Conclusions obtained as a result of this discussion were to be presented to the burgrave. However, if the city deemed a particular solution unfavourable, it could submit its objections to the commission ${ }^{57}$.

A very interesting and important part of the document are the following questions: 1) how to improve the cultivation of the soil on Warmia? Should flax crop be limited in favour of other cereals? 2) What laws are needed for servants and day labourers to establish a uniform practice in Warmia? Should the custom of the landlord giving a part of the field to smallholders for their own use be preserved? 3)How to prevent inconveniences to landlords in hiring servants? Should the uniform fee be established, the so called Gewissgeld? 4) How to define the responsibilities of smallholders and landless peasants so that they would not multiply their demands and were useful for the landlords? 5) How to prevent the devastation of forests? How to effectively reduce the amount of windthrow? How to save firewood in the countryside? How to encourage tree planting and forest protection? 6) How to dig drainage ditches without confusing the demarcations of property borders? 7)How to prevent fires? Should a form of insurance (Feyercas-

${ }^{54}$ A. Eichhorn, op. cit., p. 459.

${ }^{55}$ The entire text of the proclamation is preserved by Józef Kattenbrigk in ,Miscallanea Varmiensia'; see: AAWO, AB, H 19, pp. 103-106.

${ }^{56}$ After A. Szorc, op. cit., p. 50.

${ }^{57}$ AAWO, AB, H 19, p. 103-104. 
sa) be established for victims of fires? Should fire regulations (Brandordnung) be adopted and in what form? 8) How to revive trade in the cities? 9) How to ensure the development of crafts while keeping the craftsman taxes, especially in the case of daily use commodities? How to remove abuses which have crept into the craft guild regulations (wilkierze)? 10) Determine the wages for hired workers and set out requirements for them. They cannot change workplaces without permission. 11) How to cost-effectively decorate the exterior of the city buildings and ensure its unified style? How to obtain the sufficient amount of lime and brick in order to replace the wooden constructions? 12) Establish fair laws for mills. 13) What rules to introduce for dressing of different social groups? How to uproot the habit of inviting a large number of guests to weddings, christening and birthday parties and other feasts and to eliminate their unhealthy lavishness? 14) How to prevent the vagrants from inhabiting vacant dwellings (Brachstuben)? The text is ended with an appeal to respond to other issues which were not included in the question $s^{58}$.

There could have been at least ten survey responses ${ }^{59}$ (as much as there were districts), yet if cities sent their own replies, the number could have been higher. To date, only four survived: from Dobre Miasto ${ }^{60}$, Pieniężno ${ }^{61}$, Olsztyn $^{62}$ and Frombork ${ }^{63}$. The signatures on these documents, even if their scarcity limits the possibility of interpretation, suggest that there might have been more than ten but less than the number of cities and districts. While in the case of Pieniężno the name of the city is overtly stated ${ }^{64}$, in the case of Olsztyn there is no mention of that either at the beginning or at the end of the survey. However, there is a reference in the response to question 11 to an official letter sent to the commission by the city ${ }^{65}$. Despite the fact that it is currently impossible to determine what the exact number of surveys was, we can assume that there were at least a dozen or so.

The differences appearing in these documents are insignificant. However, while the answers may often seem similar, the approach to the problems and the stress placed on particular issues is very different. The responses involve, first and

${ }^{58}$ The text of the questions after: A. Szorc, op. cit., pp. 50-51; except question 14. Rev. prof. Szorc translated it as follows: ,how to prevent the idle and work-shy servants from entering unsuitable premises (inns)'; see: ibid., p. 51; in the original the question is put thus: ,Was für Mittel vorzukehren, das den Umtreiberischen und loosen Gesindel in denen Brachstuben kein Auffenthalt gestattet werde'; see: AAWO, AB, H 19, p. 106; however, the question does not concern the servants (Gesinde), but the riff-raff (Gesindel). Moreover, the measures taken were not intended at driving them away from inns (Krüge), but at not letting them inhabit vacant dwellings (Brachstuben).

${ }^{59}$ This is what A. Szorc reports; see: idem, Wilkierze warmińskie, p. 51.

${ }^{60}$ It is preserved in the copy by Rev. Kattenbringk; see: Ankieta z Dobrego Miasta, AAWO, AB, H 19, pp. 106-111.

${ }^{61}$ Ibidem, AK, Rep. 128/ IV-17.

${ }^{62}$ Ibidem.

${ }^{63}$ Ibidem, Rep. 128/ VIII-23.

${ }^{64}$ Ibidem, Rep. 128/IV-17, k. 327; 'Treügehorsamste Dinner und Vasallen, Magistratus et Communitas'.

${ }^{65}$ Ibidem, (no pagination); 'Cammer-Amt-Allenstein ut Supra'. 
foremost, the problems related to local societies; nevertheless, there is a clearly visible care for the whole dominion as well. Undoubtedly, the surveys constitute an interesting testimony of the era. They point to the problems affecting the privileged Warmia groups throughout their social and economic life. It is difficult to judge, however, what impact these responses had on the shape of the regulations due to the fact that only a small part of them has survived to this day. It can be assumed that they must have been read carefully. In the case of the establishment of the General Fund for Fire Protection (Powszechna Kasa Ogniowa), the text states that the Fund is introduced despite the reluctance on the part of the respondents ${ }^{66}$.Moreover, uniform prices for craft goods had not been set as there was no consent for it in the surveys. Instead, it was decided that their proportionality to the raw materials should be controlled ${ }^{67}$. The above examples point to a relationship between the contents of the act and the surveys; in view of the later history of the ordinance, one can observe that a large number of regulations ran contrary to the suggestions submitted.

The above answers came before the Commission on 14 April 1766 in Orneta. The commission nominees from the chapteres side were: Braniewo Dean - canon Ludwik Lodron, Olsztyn mayor Krzysztof Thell, and the nobles Grzymała and Wilkaniec. The Bishop's nominees were: general treasurer - canon-Tomasz Szczepański, land judge the Lidzbark starosta - Karol Grochowolski (he fell ill and was replaced by Orneta burgrave Kazimierz Józeg Płocki), and the nobles: Quoss, heir to Barkweda and Droszewo, Gotfryd Hattyński, heir to Lemity and Kłopotów, Nycz, heir to Ramsowo; in addition, mayor of Stare Miasto Braniewo Franciszek Östreich, mayor of Lidzbark Sachs, mayor of Orneta Kacper Geritz, and the Warmia treasurer' clerk Florian Gerick ${ }^{68}$.

The Commission discussed and worked on the text of the ordinance for 8 days. In addition to surveys, former ordinances were also used in the preparation of the new one. The finished text was sent to Frombork, where the chapter reviewed it from 26 to 29 April. Then, it was forwarded to the Bishop Grabowski via Tomasz Szczepanski, suggesting that one of the canons should examine it carefully in order to make corrections before the publication. The same is repeated in a letter to the Bishop of 2 May. Grabowski, in his letter to the chapter of 10 May, praises its efforts in creating the new law and states that it may already be published and that he had ordered Szczepański to do it. After reading the letter on 23 May, the chapter also instructed Szczepański to announce it publicly ${ }^{69}$. The text was printed in the Jesuits' printing house in Braniewo, and was eventually published on 4 July 1766.

\footnotetext{
${ }^{66}$ Ordynacja, Caput VI, $\$ 14$.

${ }^{67}$ Ibidem, Caput VII, $\$ 13$.

${ }^{68}$ AAWO, AB, H 19, p. 103; A. Szorc, op. cit., p. 52.

${ }^{69}$ Ibidem, p. 52.
} 
The act is divided into eighteen chapters, which in turn are subdivided into articles. The issues it concerns are close in many points to the Ferbier's ordinance, yet they also tackle the contemporary matters regarding fire insurance or shared treasuries. In many articles, one can observe the desire of the legislator to reform the Warmia region, strengthen its economy and gain more independence in trading with Prussia. The act comprises the following chapters: 1 . On flax, livestock and agricultural improvements, 2. On apprentices, servants and their daily wages, 3. On the duties and conditions of gardeners, rent-paying peasants and day labourers, 4 . On the devastation of forests, its causes and ways to mend it in order to save as much of the forests as possible, 5. On drainage ditches in meadows, so that they prevent border disputes, 6 . On preventing losses by fire, safety regulations and the Fire Protection Fund, 7. Ways to revive city trade, 8. On craftsmen emancipation and appropriate pricing of diverse handicraft products, 9. On decorating city houses, 10. On beggars, 11. On mills, 12. On proper dressing, 13. On feasts, weddings, and birthday and christening celebrations, 14. On vagabonds, 15. On inheritance and bequests 16 . On poaching, culling and malpractices in fish economy, 17. What else is needed for the trade to flourish and the country to be successful, 18 . On shared treasuries.

The autonomy and specificity of this small state, Warmia, resulted in the creation of its peculiar ,microclimate', which encompassed its society, economy, and customs alike. These features were gradually developed due to Warmia's separation from Poland, its status as a periphery, as well as its area being surrounded on all sides by the Lutheran Prussia. As a result, Warmia evolved slowly while still maintaining its old traditions, the striking evidence of which we can find in its legislation. The Warmia domestic laws were, on the one hand, an example of this, yet on the other, they frequently offered contemporary solutions, possibly modelled on the neighbouring Prussia. By way of conclusion, it should be noted that the Warmia's legislation was one of the elements of the region's specificity as it formed part of its originality and distinctness from the Prussian province as well as the Polish Republic.

\section{Jerzy Kiełbik, Administracja Warmii w świetle ustaw krajowych}

\section{Streszczenie}

Autonomia i specyfika Warmii, tego małego kraiku, powodowały, że panował w nim swoisty „mikroklimat”. Obejmował on społeczeństwo, gospodarkę, także obyczajowość. Cechy te pogłębiane były, przez odcięcie od Polski, pozostawanie na peryferiach, otoczenie zewsząd przez luterańskie Prusy. W efekcie Warmia zmieniała się powoli, ewoluowała, pozostając jednak wciąż mocno tradycjonalistyczną, czego ewidentne dowody znajdujemy w zakresie prawa. Warmińskie ustawy krajowe były z jednej strony tego przykładem, zawierały jednak niekiedy rozwiązania nowoczesne, czego być może wzorcem były sąsiednie Prusy. Niniejszy artykuł stanowi syntetyc- 
zny zarys dziejów zarządzania Warmią oraz zbiór informacji na temat podstawowych aktów prawnych, którymi kierować się musieli mieszkańcy w swoim życiu prywatnym - ustawach krajowych. Przeanalizowane zostały również najważniejsze etapy prowadzące do ukształtowania się ustroju Warmii w swej podstawowej formie oraz relacje pomiędzy biskupem, a kapitułą katedralną.

\section{Jerzy Kiełbik, Die Verwaltung Ermlands im Lichte der Landesgesetze}

\section{Zusammenfassung}

Die Autonomie und Spezifik Ermlands sorgten für ein besonderes „Mikroklima“ dieses kleinen Landes. Es umfasste die Gesellschaft, die Wirtschaft und die Sitten. Diese Eigenschaften der Region wurden durch ihre Abtrennung von Polen, ihre periphere Lage und die Umgebung durch lutherisches Preußen noch stärker. Infolgedessen änderte sich Ermland sehr langsam, diese Wandlungen zeugten davon, dass das Land stark traditionell blieb, was sich auf dem Gebiet des Rechts besonders bemerkbar machte: Die Gesetze in Ermland waren ein Beispiel dafür. Andererseits waren manche Lösungen sehr modern, vermutlich kam dieser Einfluss aus dem benachbarten Preußen. Der vorliegende Beitrag ist eine synthetische Skizze zur Geschichte der Verwaltung Ermlands, sie enthält diverse Informationen zu Grundgesetzen - den Landesgesetzen, die das private Leben der Bewohner bestimmt haben. Es wurden auch die wichtigsten Etappen in der Bildung des politischen Systems in Ermland in seiner Grundform sowie die Relationen zwischen dem Bischof und dem Domkapitel besprochen.

Übersetzt von Alina Kuzborska

dr Jerzy Kiełbik

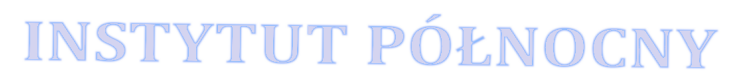

Óśrodek Badań Naukowych

im. Wojciecha Kętrzyńskiego w Olsztynie

The Wojciech Kętrzyński Research Centre

in Olsztyn

jerzy.kielbik@obn.olsztyn.pl

\section{Primary sources}

Archiwum Archidiecezji Warmińskiej w Olsztynie (AAWO)

Akta Kapituły

AK, Ab 38; AK, Rep. 128/ IV-17; AK, Rep. 128/ VIII-23; Rep. 128/IV-17

Akta Biskupie

AB, H 19

\section{Secondary sources}

\section{Kromer M.}

1977. Polska czyli o położeniu ludności, obyczajach, urzędach i sprawach publicznych Królestwa Polskiego księgi dwie, Olsztyn.

Ustawa

2010. Ustawa krajowa biskupa Adama Stanisława Grabowskiego z 4 lipca 1766 roku, ed. by. J Kiełbik, M. I. Sacha, Olsztyn.

\section{Studies}

Achremczyk S.

1993. Szlachta na Warmii XVI-XVIII wieku, in; Szlachta i ziemiaństwo na Pomorzu $w$ dobie nowożytnej XVI-XX wieku (Przemiany struktur wewnętrznych), ed. by. J. Dygdała, Toruń. 
Berg T.

1998. Landesordnungen in Preußen vom 16. bis zum 18. Jahrhundert, Lüneburg.

Biskup M., Labuda G.

1988. Dzieje Zakonu Krzyżackiego w Prusach. Gospodarka - Społeczeństwo - Państwo - Ideologia, Gdańsk. Bogdan D.

1994. Sejmik warmiński w XVI i pierwszej połowie XVII wieku, Olsztyn.

2013. Warmińska ordynacja krajowa "Landesordung” $z 1526$ roku $i$ kwestia udziału w jej redakcji Mikołaja Kopernika, Komunikaty Mazursko-Warmińskie, nr 2, pp. 283-293.

Borawska T.

1984. Tiedemann Giese (1480-1550) w życiu wewnętrznym Warmii i Prus Królewskich, Olsztyn. Eichhorn A.

1863. Geschichte der ermländischen Bischofswahlen, Zeitschrift für die Geschichte und Altertumskunde Ermlands, Bd. 2, pp.

Encyklopedia Górski K.

1958. Encyklopedia staropolska ilustrowana, ed. by. Z. Gloger, vol. 4, Warszawa.

Kiełbik J.

1977. Problematyka dziejowa Warmii, Komunikaty Mazursko-Warmińskie, nr 2, pp.

2002. Ankieta dobromiejska, Komunikaty Mazursko-Warmińskie, nr 4, pp. 527-533.

2002. Ustawa krajowa Adama Stanisława Grabowskiego z 4 lipca 1766 roku, Komunikaty Mazursko-Warmińskie, nr 2, pp. 213-240.

2003. Komornictwa kapitulne wobec reformy społeczno-gospodarczej z 1766 roku, Komunikaty Mazursko-Warmińskie, nr 2, pp. 221-235.

2006. Wspótpraca ponad granica. Kontakty Warmii i Prus Książęcych w XVI wieku, Komunikaty Mazursko-Warmińskie, nr 2, pp. 219-223.

Kopiczko A.

1993. Ustrój i organizacja diecezji warmińskiej w latach 1525-1772, Olsztyn.

Labuda G.

1969. Środowisko geograficzne, in: Historia Pomorza, vol. I: do roku 1466, ed. by. G. Labuda, Poznań. Leśnodorski B.

Nowak W. 1949. Dominium warmińskie (1243-1569), Poznań.

1999. Geneza agendy biskupa Marcina Kromera, in: Agendy i rytuały Diecezji Warmińskiej (1574-1939), ed. by. W. Nowak, Olsztyn.

Obłąk J.

1959. Historia Diecezji Warmińskiej, Olsztyn.

Olczyk A.

1961. Sieć parafialna biskupstwa warmińskiego do roku 1525, Lublin.

Poschmann A.

1910. Die Siedlungen in den Kreisen Braunsberg und Heilsberg, Braunsberg. Sikorski J.

1978. Monarchia polska i Warmia u schyłku XV wieku. Zagadnienie prawno-ustrojowe ipolityczne, Olsztyn. Szorc A.

1972. Zagrożenie Warmii przez Prusy (1722-1772), Komunikaty Mazursko-Warmińskie, nr 4. 1984. Wilkierze warmińskie, Studia Warmińskie, t. XXI, pp.

1990. Dominium warmińskie 1243-1772. Przywilej i prawo chetmińskie na tle ustroju Warmii, Olsztyn 1990.

1991. Dzieje Diecezji Warmińskiej, Olsztyn.

1999. Dzieje Warmii 1454-1660. Stan badań i postulaty badawcze, Olsztyn.

Zajchowska S. 
1953. Geografia, in: Warmia i Mazury, ed. by. S. Zajchowska i M. Kiełczewska-Zaleska, vol. II, Poznań.

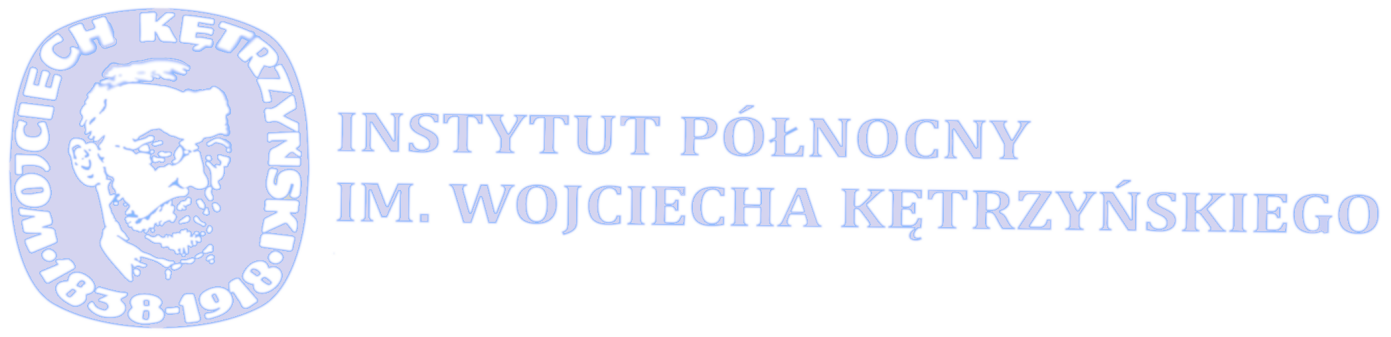

